\title{
PHYSALIS MACROPHYSA (SOLANACEAE: PHYSALINAE: SUBGENUS RYDBERGIS), ITS TAXONOMIC DISPOSITION AND RELATION TO OTHER MATERIAL WITH LARGE INFLATED FRUITING CALYCES
}

\author{
Milo Pyne \\ NatureServe /UNC-CH Herbarium (NCU) \\ University of North Carolina at Chapel Hill \\ Campus Box 3280 \\ Chapel Hill, North Carolina 27599-3280, U.S.A. \\ milopyne@yahoo.com
}

\author{
Steve L. Orzell \\ Avon Park Air Force Range \\ 29 South Blvd. \\ Avon Park AFR, Florida 33825, U.S.A.
}

\author{
Edwin L. Bridges \\ 5904 72nd Ave., NW \\ Gig Harbor, Washington 98335, U.S.A.
}

\begin{abstract}
Examination of the lectotype and isotype material of Physalis macrophysa Rydb. show its compatibility with P. longifolia, having nearly glabrous, ovate-lanceolate to broadly lanceolate leaves, and the presence of short, simple antrorse hairs on the petioles and pedicels. Other than its large inflated fruiting calyces $(3.0-4.0 \mathrm{~cm} \times 2.5-3.0 \mathrm{~cm})$, it has little in common morphologically with another large inflated calyced Physalis macrosperma which is endemic to deep sands from a portion of the West Gulf Coastal Plain of the United States. Instead, P. longifolia has stems and pedicles that are either nearly glabrous or with antrorse, appressed, non-glandular hair and ovate-lanceolate leaves versus short glandular and non-glandular, spreading, upright hair and cordate to truncate leaves in the aforementioned Physalis macrosperma. We agree with previous authors that P. macrophysa Rydb., if meriting taxonomic status, should be treated as P. longifolia var. subglabrata (Mack. $\&$ Bush) Cronquist forma macrophysa (Rydb.) Steyermark or, alternatively, it may simply represent variation within $P$. longifolia not deserving of any taxonomic status.
\end{abstract}

\section{RESUMEN}

El examen del material del lectotipo e isotipo de Physalis macrophysa Rydb. muestra su compatibilidad con P. longifolia, con hojas que son casi glabras, lanceoladas ovadas a ampliamente lanceoladas, y la presencia de pelos cortos y simples en los pecíolos y pedicelos. Aparte de sus cálices grandes inflados en la fructificación $(3.0-4.0 \mathrm{~cm} \times 2.5-3.0 \mathrm{~cm})$, tiene poco en común morfológicamente con el otro cáliz grande inflado Physalis macrosperma de arenas profundas que es endémica a una parte de la llanura costera del golfo oeste de los Estados Unidos. En cambio, P. longifolia tiene tallos y pedicelos que son casi glabros o con pelos antrorsos, adpresos, no glandulares y hojas ovado-lanceoladas, versus pelos cortos glandulares y no glandulares que se extienden hacia arriba y hojas cordadas y truncadas. Estamos de acuerdo con autores anteriores en que P. macrophysa Rydb., si merece un estatus taxonómico, debe tratarse como P. longifolia var. subglabrata (Mack. \& Bush) Cronquist forma macrophysa (Rydb.) Steyermark o, alternativamente, puede representar simplemente una variación dentro de $P$. longifolia que no merece ningún rango taxonómico.

Key Words: Physalis, macrophysa, lectotype, isolectotype, Solanaceae

\section{INTRODUCTION}

The diverse, primarily New World, genus Physalis L. (Solanaceae, subtribe Physalinae sensu Hunziker 2001) contains 75-90 species worldwide. The 24 US species (Sullivan in press) have a complicated history with conflicting taxonomic treatments for many of the recognized taxa (Rydberg 1896; Waterfall 1958; Sullivan in press). Among the troublesome are those with inflated fruiting calyces that have long attracted the attention of taxonomists. While the calyx traits can be important taxonomic characters (Wilf et al. 2017), many aspects of the calyx morphology are difficult to quantify and can be lost or obscured in the drying and pressing of specimens. There are large-calyced plants from the eastern and central United States which are part of the P. longifolia complex (includes varieties of $P$. longifolia var. subglabrata and $P$. longifolia var. texana in addition to the nominate variety). These plants have round-ovoid fruiting calyces which measure ca. $4 \mathrm{~cm}$ long and abruptly taper to the lobes. Rydberg (1895) proposed a species rank for this material with large calyces, applying the 
name P. macrophysa. Waterfall (1958) reduced this to formal status but as a form of "P. virginiana." His concept of $P$. virginiana is a very broad one, including what current authors call $P$. longifolia. In addition, there are largecalyced forms of $P$. virginiana as well as a separate large-calyced entity which we are proposing to describe as a new species.

Our study aims to determine how these large-calyced plants compare with one another and whether any of them deserve taxonomic recognition, and, if so, at what rank? We clarify the disposition of $P$. macrophys $a$ and the other inflated fruiting calyx Physalis within P. virginiana and P. longifolia in relation to another large inflated-calyced Physalis macrosperma that is endemic to deep sands found in portions of the West Gulf Coastal Plain of the United States.

\section{METHODS}

A review of existing taxonomic treatments of Physalis was supplemented with herbarium surveys. The senior author examined over 900 sheets of Physalis from 24 herbaria (BRIT, BRIT-VDB, CM, DUKE, GH, K, LAF, LSU, MO, NCSC, NCU, NLU, NMC, NY, P, RM, SIU, SMU, TEX, TEX-LL, UC, US, USCH, and USF). Both literature and examination of herbarium specimens helped identify other Physalis bearing highly inflated fruiting calyces. The senior author also examined the lectotype and isolectotypes (NY, UC, US) of P. macrophysa Rydb.

RESULTS AND DISCUSSION

\section{Rydberg's Concept of Physalis macrophysa}

Physalis macrophysa was named by P.A. Rydberg (1895) based on material from Arkansas and Texas, north and east to Kansas, Ohio, and North Carolina (Table 1). As the name indicates, its primary distinguishing feature is its inflated fruiting calyx, which he described as measuring "3-4 centimeters long, 2.5-3 centimeters in diameter, pyramidal to ovoid-conical, indistinctly 10-angled, deeply sunken at the base; berry small, in the center of the calyx" (Fig. 1) (Rydberg 1895, 1896). Rydberg did not designate a holotype but he did cite seven specimens: one each from Arkansas, Kansas, and North Carolina and two each from Texas and Ohio. The question mark "?" by the North Carolina and Ohio citations indicates he was dubious about these determinations.

Physalis macrophysa was reduced to a form of Physalis virginiana by Waterfall (1958). He designated lectotype and isolectotype material (Heller 1756 NY!, UC!) chosen from among the specimens cited by Rydberg. This type material was examined, as well as additional duplicates of Heller 1756 not cited by Waterfall, and other specimens cited by Rydberg or Waterfall as belonging to this taxon.

Rydberg did not indicate the herbarium repositories housing the specimen(s) of Heller 1756 (collected Kerrville, Kerr County, Texas, 17 May 1894) that he examined when naming P. macrophysa. However, there are two sheets housed at NY, neither of which was determined by Heller as to species, but which were annotated by Rydberg as P. macrophysa and which were subsequently designated as lectotype (barcode NY00138844; Fig. 2) and isolectotype (barcode NY00138845; Fig. 3) by Waterfall (1958). There is also one sheet at UC (accession UC104012; Fig. 4), apparently not examined by Rydberg, which Waterfall (1958) examined, annotated as isolectotype, and cited. Heller determined this sheet as P. peruviana L. In addition, there is a sheet of this collection at US (accession US213409; Fig. 5) which was annotated by Rydberg as a "syntype" of P. macrophysa but was apparently neither examined nor cited by Waterfall. It has been labeled as a type collection by the US herbarium. These are the only sheets of Heller 1756 of which we are aware, but there could be others.

In addition to the collections listed above, there are holdings of a collection (U.S.A., New Mexico, Doña Ana Co., Mesilla; 3900 ft, 22 Jun 1898, Wooton 52) in several US and foreign herbaria, including K, MO, NMC, NY, P, and RM. All of these sheets bear printed labels indicating a determination by Rydberg as "Physalis macr(o)physa Rydb." When possible, images of these specimens have been examined. They all appear compatible with P. longifolia and have the narrower leaves characteristic of the nominate and western varieties of this species.

Rydberg included P. macrophysa in his Flora of the Prairies and Plains (1932) and in his Physalis treatments 
TABLE 1. Collections cited by Rydberg $(1895,1896)$ as representing Physalis macrophysa Rydb. * Rydberg expressed doubt ("?") as to the identity of these collections.

\begin{tabular}{|c|c|c|c|}
\hline State & Collector/number & Date & Notes \\
\hline Arkansas & A.E. Heacox s.n. & 20 Jul 1889 & MU! (isosyntype) $=$ P. subglabrata \\
\hline Kansas & E.A. Popenoe 68 & 1875 & Not seen \\
\hline * North Carolina & Small \& Heller 389 & 25 Jun 1891 & $\begin{array}{l}\text { NY! = P. virginiana (fide UTW); "Banks of the } \\
\text { Yadkin River, near the foot of Rip Shin Mountain” }\end{array}$ \\
\hline * Ohio & F.H. Horsford s.n. & 1879 & Not seen \\
\hline * Ohio & C.W. Short s.n. & n.d. & $\begin{array}{l}\text { MO! "a common garden weed; root perennial"; } \\
\text { "Hab. Fernbank - ad fluminis Ohio, } \\
\text { prope "North Bend." = P. subglabrata }\end{array}$ \\
\hline Texas & Lindheimer s.n. & 1828 & MO! "Braunfels" \\
\hline Texas & A.A. Heller 1756 & 17 May 1894 & $\begin{array}{l}\text { NY! - } 2 \text { sheets "Kerrville, Kerr County"; } \\
\text { "Elevation, } 1600-2000 \text { feet" }\end{array}$ \\
\hline
\end{tabular}

Io. Physalis macróphysa Rydb. Largebladder Ground-Cherry. Fig. 3705.

P. macrophysa Rydberg, Bull. Torr. Club $22: 308$. 1895 .

Perennial; rootstock rather thick and fleshy; stem erect, $\mathrm{I}_{\frac{1}{2}}^{\circ}-3^{\circ}$ high, comparatively slender, angled, perfectly glabrous, or the upper parts sparingly pubescent with very short hairs. Leaves large, thin, $I^{\frac{1}{2}}-3^{\frac{1}{2}} \mathbf{2}^{\prime}$ long, $I^{\prime}-2^{\prime}$ wide, the lower obtuse, the upper acute or acuminate; petioles slender, $\mathbf{I O}^{\prime \prime}-2 \mathrm{O}^{\prime \prime}$ long; peduncles $5^{\prime \prime}-8^{\prime \prime}$ long, erect, in fruit reflexed; calyx smooth, its lobes ovate-triangular or broadly lanceolate, generally a little shorter than the tube; corolla yellow with a dark center, about Io" $^{\prime \prime}$ in diameter; anthers generally yellow, sometimes tinged with purple; fruiting calyx large, $\mathrm{I}^{\prime}-\mathrm{I}^{\frac{1^{\prime}}{2}}$ long, $\mathrm{I}^{\prime}-\mathrm{I}^{1^{\prime}}$ in diameter, pyramidal to ovoid-conic, indistinctly ro-angled, deeply sunken at the base; berry small, in the center of the calyx.

In rich soil, Kansas and Arkansas to Texas. MayJuly. Rare.

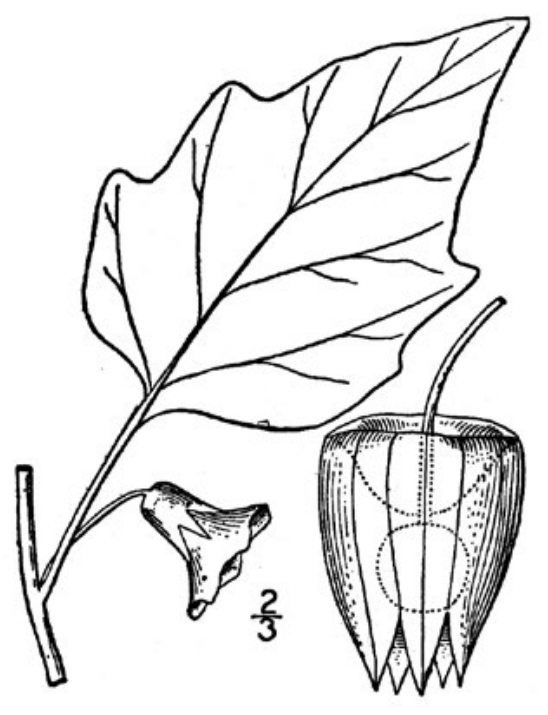

FIG. 1. Description and illustration of Physalis macrophysa Rydb. from Britton and Brown (1913). It should be noted that among the lectotype and isolectotype material (Heller 1756 NY!, UC!, US!) this illustration most closely resembles the lectotype at NY, as it should, with the qualification that the fruiting calyx on this sheet has deteriorated over time and much of its tissue has been lost, with its outline being penciled in by an unknown researcher or curator. The isolectotype is in flowering condition, without fruiting calyces.

for other manuals (Rydberg 1898, 1903, 1913a, 1913b) but it did not appear in his treatment for Small's Manual (Rydberg 1933) due to the different range of this latter work. The key provided in the 1932 work separates $P$. macrophysa from P. longifolia and P. subglabrata based on the fruiting calyx shape which is given as "pyramidal, very much inflated, and deeply sunken at the base" in P. macrophysa and as "ovoid, nearly filled with the berry, scarcely sunken at the base" in the latter two taxa. The range of P. macrophysa is given as "Ark.-Kans.-Tex." (Rydberg 1932).

\section{Waterfall's Concept of Physalis macrophysa}

Waterfall (1958) reduced P. macrophysa to formal rank as "Physalis virginiana f. macrophysa (Rydb.) Waterfall, comb. et stat. nov.," citing Rydberg's description. This version of the new combination does not specify which one of his varieties of $P$. virginiana this taxon is a form of, but the combination appears under the discussion of 


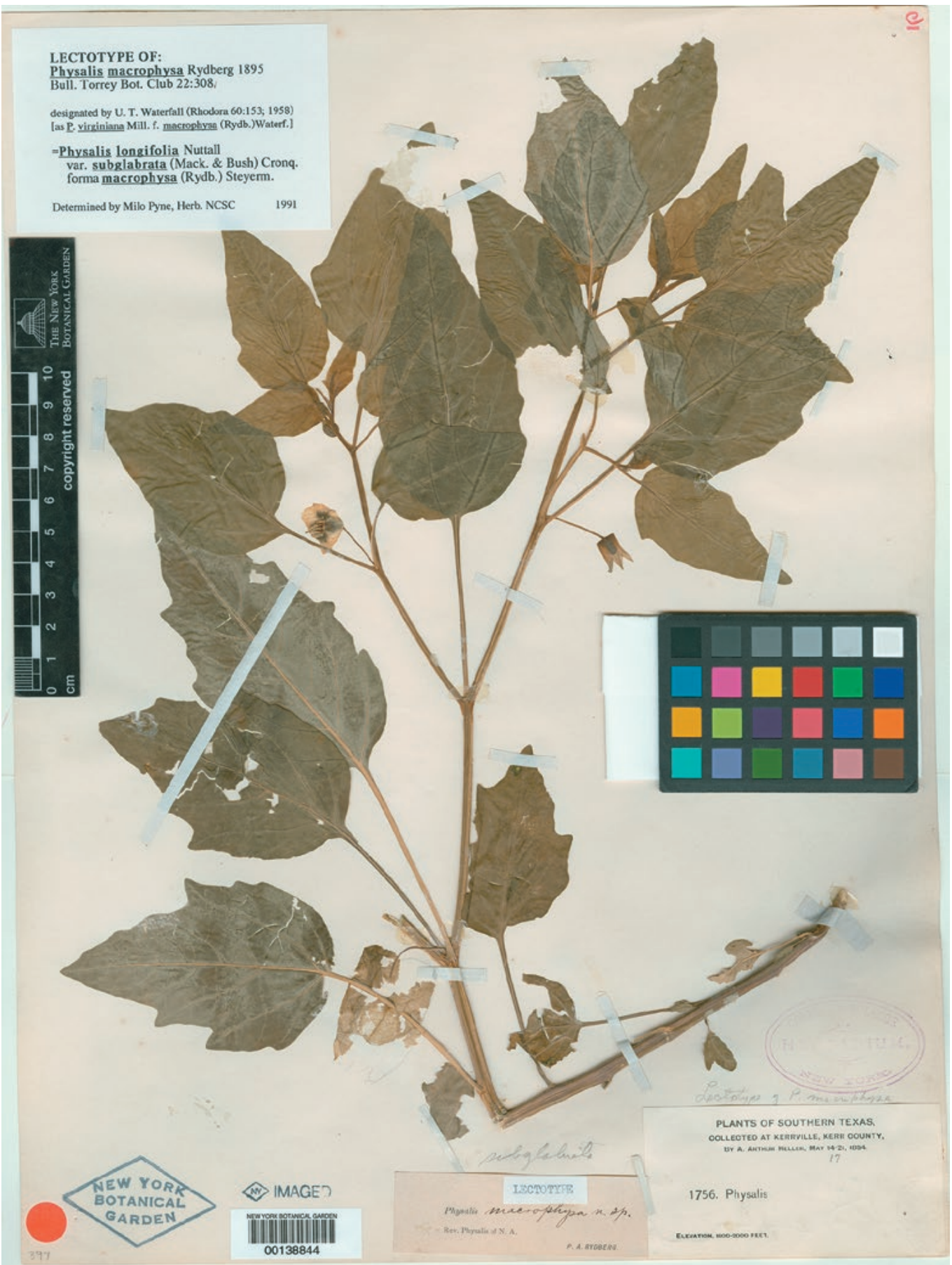

FIG. 2. Lectotype of Physalis macrophysa Rydb. Heller 1756, Kerrville, barcode NY00138844; designated and cited by Waterfall (1958) (reproduced courtesy of Herbarium NY). 


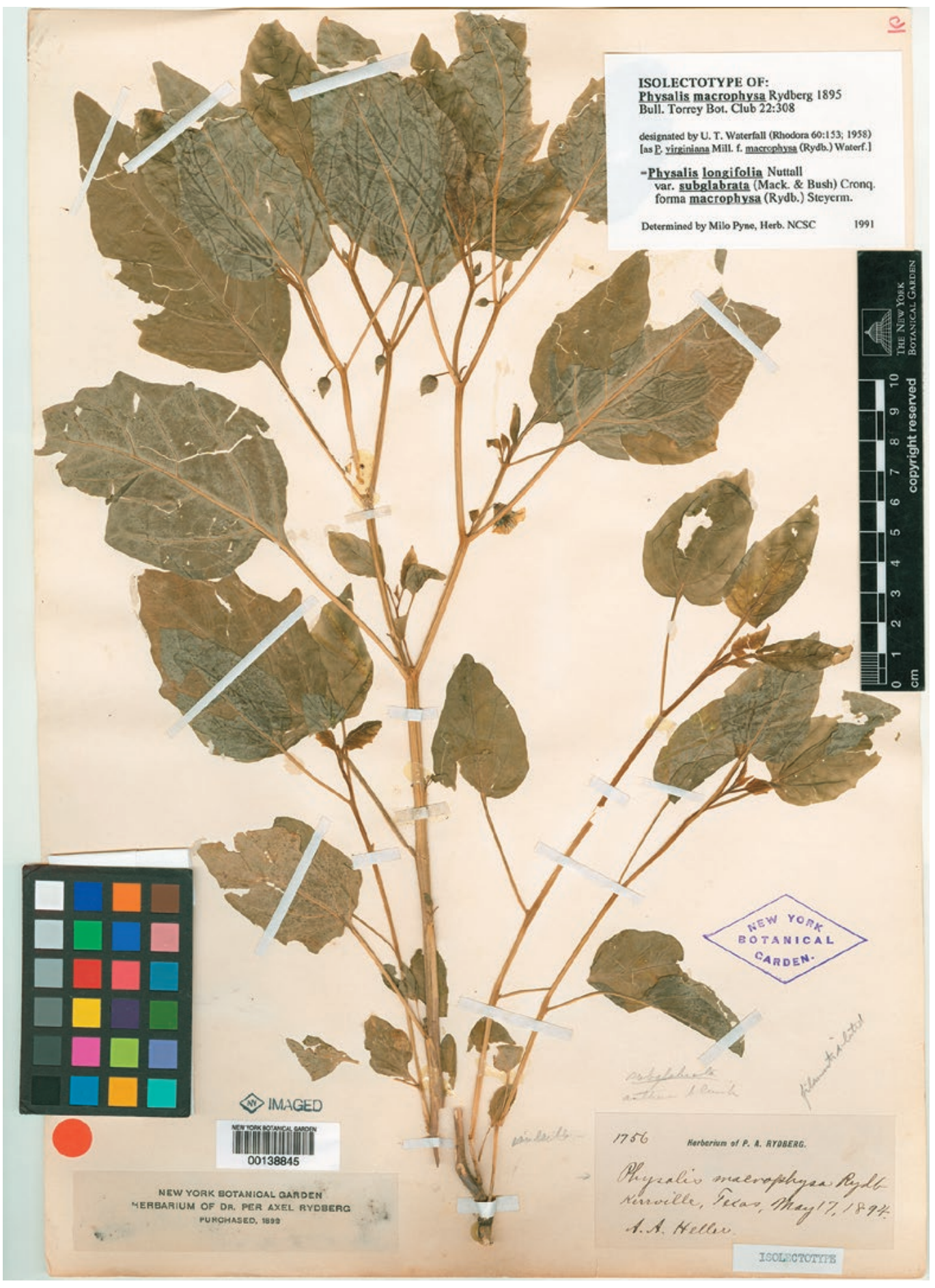

FIG. 3. Isolectotype of Physalis macrophysa Rydb., Heller 1756, Kerrville, barcode NY00138845; designated and cited by Waterfall (1958) (reproduced courtesy of Herbarium NY). 


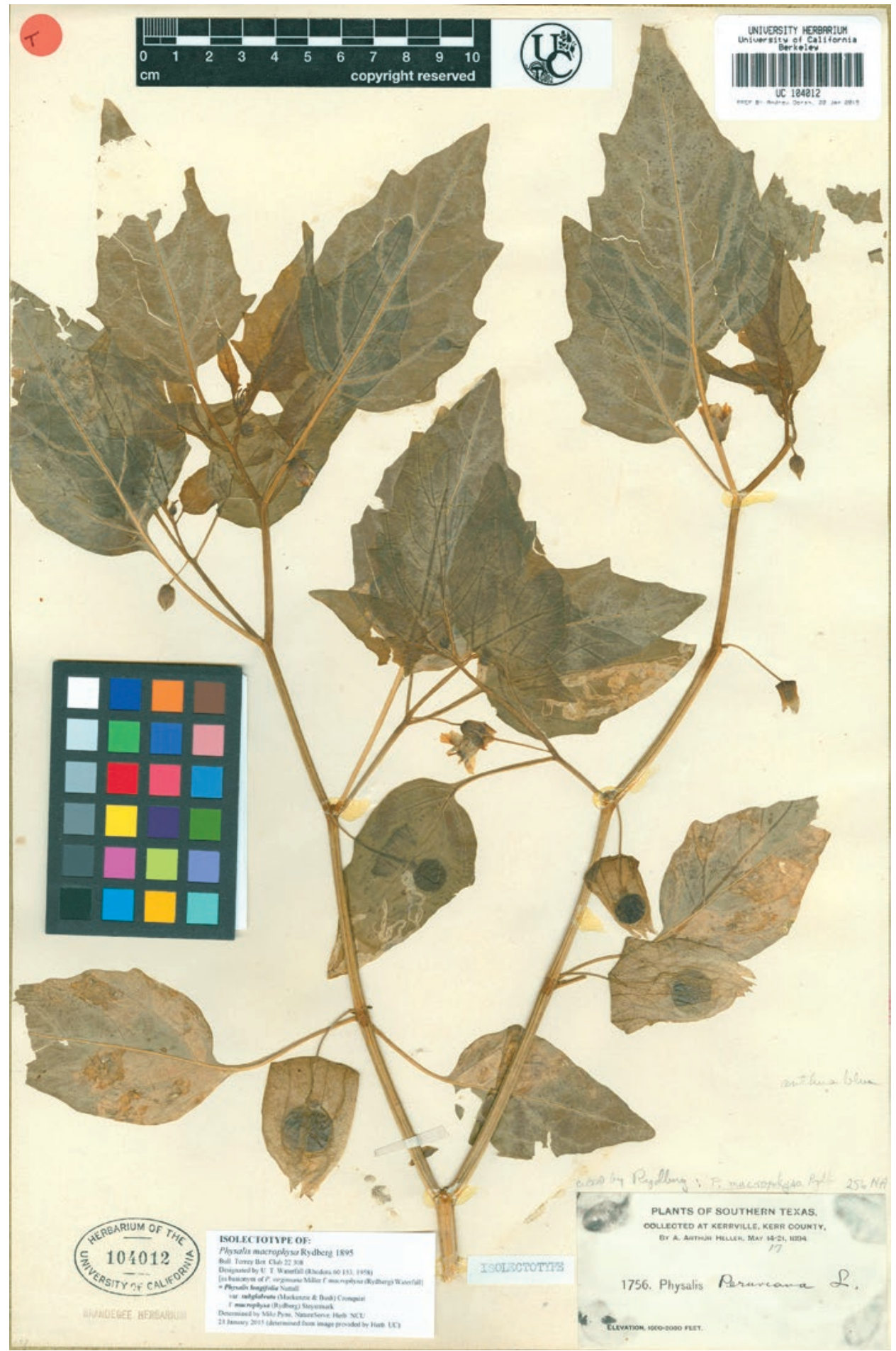

FIG. 4. Isolectotype of Physalis macrophysa Rydb. Heller 1756, accession UC104012; designated and cited by Waterfall (1958) (reproduced courtesy of Herbarium UC). 


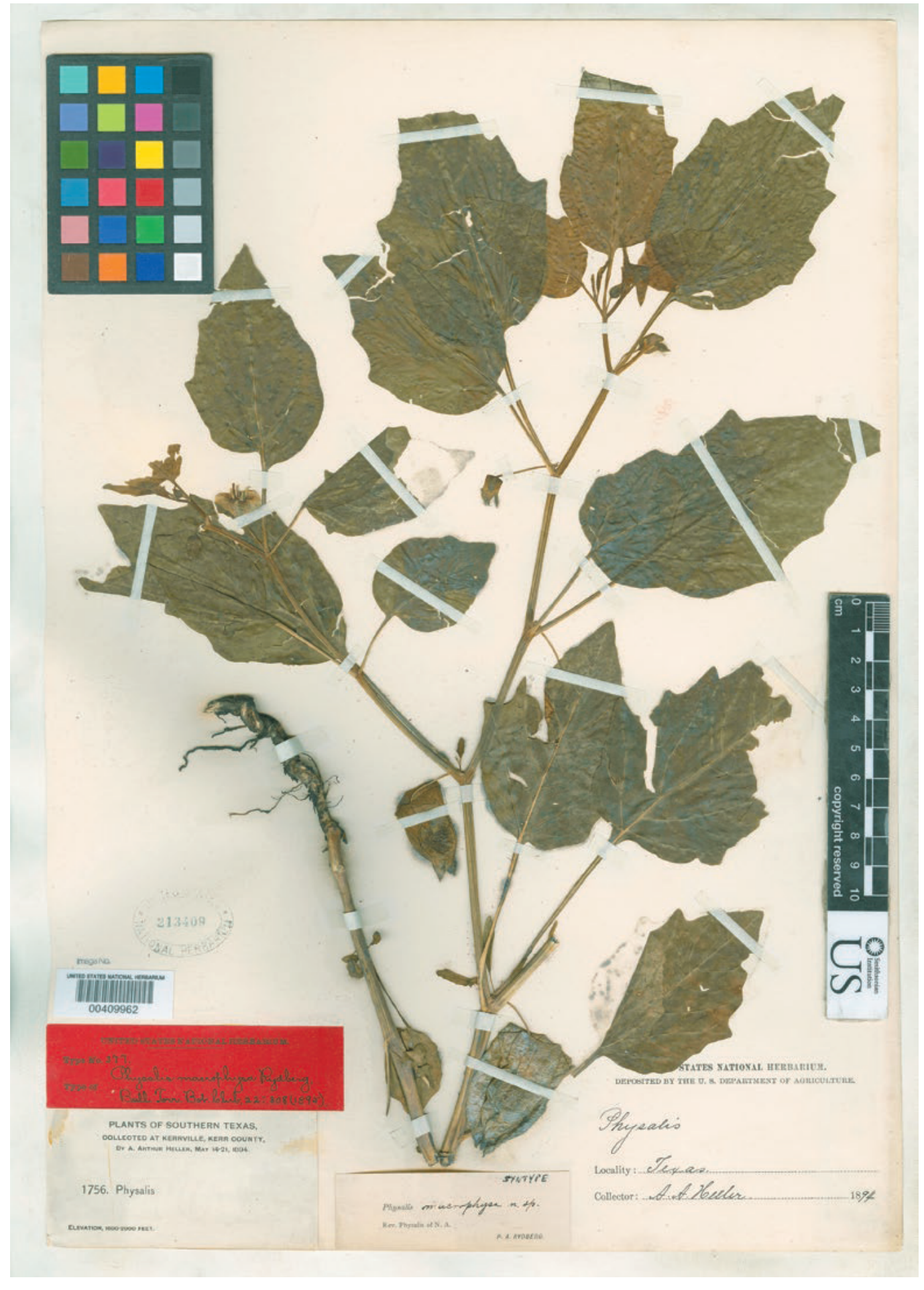

FIG. 5. Isolectotype of Physalis macrophysa Rydb. Heller 1756, accession US213409; labeled syntype by Rydberg, not cited by Waterfall (reproduced courtesy of Herbarium US). 
"9b. Physalis virginiana Miller, var. subglabrata (Mack. \& Bush) Waterfall," and it is presented in the key with the full quadrinominal, indicating that he intended to affiliate his new form with the variety subglabrata.

Waterfall employed a very broad concept of $P$. virginiana, subsuming within it, as varieties, taxa that are currently known as P. longifolia var. longifolia (as P. virginiana var. sonorae); P. longifolia var. subglabrata (as P. virginiana var. subglabrata); $P$. pumila var. hispida (as P. virginiana var. hispida), and $P$. longifolia var. texana (as $P$. virginiana var. texana). Sullivan (2013) made the transfer of the varietal epithet texana from $P$. virginiana to $P$. longifolia and conferred varietal status (rather than subspecific status) under P. pumila to var. hispida.

The "variety subglabrata" to which Waterfall assigned Rydberg's P. macrophysa as a form is better affiliated with P. longifolia rather than P. virginiana sens. str. (Cronquist 1959; Steyermark 1960, 1963; Sullivan 2004; Sullivan in press). Steyermark (1960) also confirmed the affinity of P. macrophysa with P. longifolia var. subglabrata and published the combination Physalis longifolia Nuttall var. subglabrata (Mack. \& Bush) Cronquist f. macrophysa (Rydb.) Steyermark, which is the full correct name for this entity at the formal rank.

In Waterfall's selection of the lectotype and isolectotypes for P. macrophysa, he provides no discussion of why this collection and these specimens were chosen, and no description of the taxon is given except the observation that the fruiting calyces are " $4-5 \mathrm{~cm}$. long and 3-4 cm. broad." He cited a total of 13 collections (Table 2) as belonging to P. macrophysa, from Indiana west to Nebraska and southwest to Texas, with a geographic outlier in New Jersey. Texas is the state with the largest number of cited specimens (4 of the 13). No ecological or habitat information is provided for P. macrophysa. Curiously, with the exception of the isotype material, there are no specimens in common between those cited by Rydberg (Table 1) and those cited by Waterfall (Table 2).

\section{More Recent Taxonomic Treatments}

In addition to the collections cited by Waterfall, we have located three specimens of two collections which were annotated by him in 1967 as "Physalis virginiana Miller forma macrophysa (Rydb.) Waterfall." There could be additional collections similarly annotated. These two collections are: Texas. Lamar Co.: Western Lamar Co.; Cr[eek] bottom, 14 Jun 1924, Tharp 2935 (TEX-LL; 2 sheets), initially determined as "Physalis macrophysa Rydb. / [ditto] subglabrata M \& B." This collection represents P. longifolia var. subglabrata f. macrophysa and has been annotated by the senior author as such; Montgomery Co.: "Conroe," 15 Jun 1935, Tharp s.n. (TEX-LL), initially determined as "Physalis macrophysa Rydb." In our opinion this sheet is compatible with Physalis macrosperma (Pyne et al. 2019, pp. 35, 48) and has been annotated as such. Other than the 1935 Tharp collection cited above, it is not clear that Waterfall ever saw material of the taxon we propose to call a new species of Physalis.

Menzel (1960) independently commented on the existence "in Texas (and perhaps as far north as Illinois and Indiana) of a rare form of Physalis ... characterized by a very large ... pyramidal, many-ribbed but scarcely angled, fruiting calyx, deeply sunken at the base so that the small fruit is suspended in the middle of the greatly inflated calyx." Most notably, she details "very large seeds (3-4 mm. in diameter)" of this plant. Menzel was presumably aware of Waterfall's designation of the lectotype for P. macrophysa Rydb. (Waterfall 1958), and notes that Heller 1756 (the lectotype collection) is "a representative specimen" of the plants to which she was referring except that "the plants are often somewhat hairier" than this specimen. Menzel's 1960 publication followed Waterfall's comprehensive 1958 treatment, but it is not clear when she may have viewed the two NY sheets of Heller 1756 (which have typed paper labels designating their lectotype status, presumably affixed by Waterfall). Menzel's comments about her plants being "often somewhat hairier" and having 3-4 mm seeds means that she may have been observing the new species we are proposing rather than P. longifolia, since the large-calyced forms of $P$. longifolia do not have 3-4 mm seeds. The details of this have not been fully resolved, as no collections by Menzel of this material with the 3-4 mm seeds have been located.

With the exception of Mohlenbrock $(1978,1982,1990)$, no recent workers appear to recognize P. macrophysa above the formal level. He treats it as a species and notes its presumably adventive occurrence in Illinois (1978). In addition, Mohlenbrock $(1982,1990)$ indicates that it is related to P. subglabrata Mack. \& Bush (= P. longifolia Nutt. var. subglabrata [Mack. \& Bush] Cronquist, = P. virginiana Mill. var. subglabrata [Mack. \& 
TABLE 2. Collections cited by Waterfall (1958) as representing Physalis macrophysa Rydb.

\begin{tabular}{|c|c|c|c|c|}
\hline State & County & Collector/number & Date & Herbarium/notes \\
\hline Arkansas & Marion & Demaree 20645 & 2 Sep 1939 & $\begin{array}{l}\text { NY!; "fertile White River bottoms; P.O. Flippin; } \\
\text { elevation } 650 \text { (feet)" }\end{array}$ \\
\hline Illinois & Peoria & McDonald s.n. & Aug 1903 & NY; "open rich ground" \\
\hline Illinois & Champaign & Gleason s.n. & 7 Oct 1907 & DUKE! \\
\hline Indiana & Lawrence & Kriebel 1348 & 27 Sep 1933 & DUKE! \\
\hline lowa & Story & Hayden 424 & & $\mathrm{GH}$ (not seen) \\
\hline Missouri & Jackson & Bush 12483A & 24 Jun 1932 & NY!; "Dry ground" \\
\hline Missouri & Jackson & Bush 12483 & 24 Jun 1932 & DUKE! \\
\hline Nebraska & Howard & Bates 4910 & 18 Jul1909 & $\mathrm{GH} !=$ P. longifolia var. longifolia \\
\hline New Jersey & Somerset & Lighthipe s.n. & 1 Aug 1916 & TEX!, “Rocky Hill, N.J.” \\
\hline Texas & & Lindheimer s.n. & May 1847 & GH (not seen) \\
\hline Texas & Kerr & Heller 1756 (lectotype) & 17 May 1894 & NY! 2 sheets; UC; US \\
\hline Texas & Tarrant & Ruth 746 & 27 Sep 1919 & NY!, PH "in Trinity Park" \\
\hline Texas & Travis & Tharp s.n. & 6 May 1931 & TEX (not seen) \\
\hline
\end{tabular}

TABLE 3. Selected Physalis virginiana specimens with calyx dimensions.

\begin{tabular}{|c|c|c|c|c|c|c|}
\hline State & County & Collector/number & Date & Herbarium & Length & Width \\
\hline lowa & Cedar & Fay 1130 & 25 Jul 1950 & SIU & $4.2 \mathrm{~cm}$ & $3.0 \mathrm{~cm}$ \\
\hline Kentucky & Edmonson & Palmer s.n. & May 1899 & NY & & \\
\hline Kentucky & Lyon & Eggleston 4636 & 2-18 Jun 1909 & NY & $4.0 \mathrm{~cm}$ & $2.0 \mathrm{~cm}$ \\
\hline North Dakota & Richland & Stevens s.n. & 11 July 1934 & $\mathrm{NCU}$ & $3.5 \mathrm{~cm}$ & $1.8 \mathrm{~cm}$ \\
\hline Oklahoma & Rogers & Bush 1281 & 23 May 1895 & NY & $4.2 \mathrm{~cm}$ & $3.0 \mathrm{~cm}$ \\
\hline Texas & Henderson & Correll \& Correll 38663 & 8 May 1970 & TEX-LL & & \\
\hline Texas & Smith & Reverchon 3231 & 15 May 1902 & MO & $4.2 \mathrm{~cm}$ & $3.5 \mathrm{~cm}$ \\
\hline Wisconsin & Dodge & French s.n. & Jul 1869 & SIU & $4.2 \mathrm{~cm}$ & $3.0 \mathrm{~cm}$ \\
\hline
\end{tabular}

Bush] Waterfall), and P. texana Rydb. (= P. virginiana Mill. var. texana [Rydb.] Waterfall; = P. longifolia Mill. var. texana [Rydb.] Sullivan).

We are not aware of any genetic studies that have been conducted on material attributed to P. macrophysa which would test any hypotheses related to its possible status or taxonomic rank, but in any case, it does not seem to represent a consistent entity deserving of species or varietal rank.

The distinctive large-calyced Physalis of deep sands which ranges from south-central Texas (Bexar and Wilson counties) east and north to southwestern Arkansas (Miller County) and western and north-central Louisiana is to be described as a new species (Pyne et al. 2019, this issue). It differs strongly from Physalis macrophysa, being somewhat hispid, approaching P. heterophylla in this respect, but with shorter hairs and having long-pyramidal calyces and seeds 3-4 $\mathrm{mm}$ in diameter. Numerous collections of this plant have been made by R. Dale Thomas and colleagues and the junior authors. The earliest collections we have located are the following: TEXAS. Anderson Co.: sandy ground N Palestine, 12 Jun 1892, Eggert s.n. (MO). Dallas Co.: common in fields, 2 May 1901, Reverchon 2546 (MO).

In addition, there are also rare individuals with large calyces that are allied with $P$. virginiana Mill. (Table 3). Waterfall (1958) states that "(s)pecimens with large fruiting calyces also appear in P. virginiana var. virginiana ..." but did not cite particular specimens and declined to provide any nomenclatural recognition or taxonomic status to these plants which are distinct from the material referred to P. macrophysa Rydb. The retrorse hairs on their peduncles ally them with P. virginiana sens. str. Some examples include: IOWA. Cedar Co.: 25 Jul 1950, Fay 1130 (SIU). KENTUCKY. Edmonson Co.: May 1899, Palmer s.n. (NY). Lyon Co.: 2-18 Jun 1909, Eggleston 4636 (NY). NORTH DAKOTA. Richland Co.: Kindred, dry soil on sandy prairies, 11 July 1934, Stevens s.n. (NCU). OKLAHOMA (Indian Territory). Rogers Co.: Catale, 23 May 1895, Bush 1281 (NY). 
TEXAS. Henderson Co.: on road to Lake Athens, sandy soil in post oak woods, 8 May 1970, Correll \& Correll 38663 (TEX-LL!). Smith Co.: 15 May 1902, Reverchon 3231 (MO) 2 sheets ("Lindale Tex." originally as "Physalis heterophylla $\beta$ "; annot. by [unknown] as "P. macrophysa Rydb.?"). WISCONSIN. Dodge Co.: Calamus, Jul 1869, French s.n. (SIU).

We agree with previous authors that if Physalis macrophysa Rydb. deserves any taxonomic recognition, it is only as P. longifolia var. subglabrata forma macrophysa (Rydb.) Steyermark, and our study has shown that it is not related to our proposed new species. In any case, it does not deserve species or varietal rank. It is distinct from large-calyced forms of $P$. virginiana Mill. as well as from Physalis macrosperma from deep sands that is endemic to a portion of the West Gulf Coastal Plain of the United States.

\section{ACKNOWLEDGMENTS}

Thanks are due to directors, curators, and staff at various herbaria; in particular, special thanks are extended to staff at DUKE, GH, MO, NY, SIU, TEX, UC, and US. In addition, thanks are due to Carol Ann McCormick and Shanna Oberreiter (NCU) for assistance with loans and specimen imaging, Rocío Deanna for review and assistance with translation, Maggie Whitson and Mahinda Martínez Díaz for reviews. Thanks to Janet Sullivan for guidance and technical support during manuscript preparation. We are also grateful for financial support from the Arkansas Natural Heritage Commission and assistance from the Edward C. Swab Fund for Floristic Botany of the Herbarium of the University of North Carolina at Chapel Hill to defray publication costs.

\section{REFERENCES}

Cronquist, A.E. 1959. Physalis. In: C.L. Hitchcock et al. Vascular plants of the Pacific Northwest. University of Washington Press, Seattle, Washington, U.S.A. 4:286-288.

HUNZIKER, A.T. 2001. Genera Solanacearum: The genera of Solanaceae illustrated, arranged according to a new system. A.R.G. Gantner, Ruggell, Liechtenstein, Germany.

MENZEL, M.Y. 1960. What is Physalis variovestita? Rhodora 62:117-121.

Mohlenbrock, R.H. 1978. Physalis. In: Guide to the vascular flora of Illinois. Southern Illinois Press, Carbondale and Edwardsville, Illinois, U.S.A. Pp. 381-882.

MoнLenBRock, R.H. 1982. Illinois Solanaceae in the Missouri Botanical Garden Herbarium and biographical sketches of some collectors. Ann. Missouri Bot. Gard. 69:382-392.

Mohlenbrock, R.H. 1990. The illustrated flora of Illinois. Flowering plants: Nightshades to mistletoe. Southern Illinois University Press, Carbondale and Edwardsville, Illinois, U.S.A.

Pyne, M., S.L. OrzelL, E.L. Bridges, \& D. PoindeXter. 2019. Physalis macrosperma (Solanaceae: Physalidinae), a new psammophyte endemic to the West Gulf Coastal Plain of the southeastern USA coastal plain, a biodiversity hot spot. J. Bot. Res. Inst. Texas 13:31-50.

RYDBERG, P.A. 1895. New species of Physalis and related genera. Bull. Torrey Bot. Club 22:306-308.

RYDBERG, P.A. 1896. The North American species of Physalis and related genera. Mem. Torrey Bot. Club 4(5):297-374.

RYDBERG, P.A. 1898. Physalis. In: N.L. Britton \& A. Brown. An illustrated flora of the northern United States, Canada and the British possessions: From Newfoundland to the parallel of the southern boundary of Virginia, and from the Atlantic Ocean westward to the 102d meridian. Charles Scribner's Sons, New York, New York, U.S.A. 3:125-132. (Physalis macrophysa p. 129)

RYDBERG, P.A. 1903. Physalis. In: J.K. Small. Flora of the southeastern United States. Published by the author, New York, New York, U.S.A. Pp. 981-987.

RYDBERG, P.A. 1913a. Physalis. In: J.K. Small. Flora of the southeastern United States. Published by the author, New York, New York, U.S.A. Pp. 981-987.

RYDBERG, P.A. 1913b. Physalis. In: N.L. Britton \& A. Brown. Illustrated flora of the vascular plants of the northeastern United States and Adjacent Canada, 2nd ed. Charles Scribner's Sons, New York, New York, U.S.A. 3:155-162.

RYDBERG, P.A. 1932. Physalis. In: Flora of the prairies and plains of Central North America. 1965 facsimile edition by Hafner Publishing Co., New York, U.S.A. Pp. 698-702.

RYDBERG, P.A. 1933. Physalis. In: J.K. Small. Manual of the southeastern flora. Published by the author, New York, New York, U.S.A. Pp. 1107-1112. 
Steyermark, J.A. 1960. New combinations and forms in the Missouri flora. Rhodora 62:130-132.

Steyermark, J.A. 1963. Physalis. In: Flora of Missouri. lowa State University Press, Ames, lowa, U.S.A. Pp. 1314-1322.

Suluivan, J.R. [in press]. Physalis (Solanaceae). In: Flora of North America Editorial Committee. Flora of North America north of Mexico, Vol. 14. Oxford Univ. Press, New York, New York, U.S.A., and Oxford, U.K.

Suluivan, J.R. 2013. Nomenclatural innovations in North American Physalis (Solanaceae). Rhodora 115(963):290-292.

Suluivan, J.R. 2004. The genus Physalis (Solanaceae) in the southeastern United States. Rhodora 106(928):305-326.

Waterfall, U.T. 1958. A taxonomic study of the genus Physalis in North America north of Mexico. Rhodora 60:107-114, $128-142,152-173$.

Wilf, P., M.R. Carvalho, M.A. Gandolfo, \& N.R. Cuneo. 2017. Eocene lantern fruits from Gondwanan Patagonia and the early origins of Solanaceae. Science 355:71-75. 